\title{
KREATIVITAS GURU BIOLOGI DALAM MEMETAKAN KOMODITAS HAYATI UNGGULAN LOKAL KE DALAM PEMBELAJARAN BIOLOGI SMA
}

\author{
Asep Agus Sulaeman ${ }^{1}$, Liliasari $^{2}$, Sri Redjeki $^{2}$, Dewi Sawitri $^{3}$ \\ ${ }^{1}$ PPPPTK IPA \\ ${ }^{2}$ Universitas Pendidikan Indonesia \\ ${ }^{3}$ Institut Teknologi Bandung
}

\begin{abstract}
The purposes of this study was to determine the high school biology teacher creativity in mapping topics of various aspects of local biodiversity commodities through the use of mind mapping method and determine the ability of teachers to map Biological topics of local biodiversity commodities into biology learning in secondary school. Data analysis on biology teacher creativity conducted using descriptive quantitative method upon the mind map by using the criteria matched with suggested instrument. The analysis of data on the amount of Biological topics and types of learning activities based on local biodiversity conducted by using descriptive quantitative and qualitative method. The results of this study showed the creativity value aspects from biology teachers is good, consist of the the originality $(91,67)$, the sensitivity of problem $(91,67)$, the fluency $(90)$, the flexibility $(88,33)$, and the elaboraty $(86,67)$. Based on the mapping conducted by the teachers, there were 15 biology topics related to local biodiversity commodities in Majalengka. Biology learning activities based on local biodiversity commodities suggested by teachers spread out on all grade and semester with different amount activities.
\end{abstract}

Keywords: creativity, Biology teacher, local biodiversity commodities, high school Biology lesson

\begin{abstract}
Abstrak
Tujuan penelitian ini adalah untuk mengetahui kreativitas guru Biologi SMA dalam memetakan topiktopik dari berbagai aspek komoditas hayati unggulan lokal melalui penggunaan metode mind map dan mengetahui kemampuan guru dalam memetakan topik-topik komoditas hayati unggulan lokal ke dalam pembelajaran Biologi di SMA. Analisis data kreativitas guru Biologi SMA dilakukan secara deskriptif kuantitatif terhadap mind map dengan menggunakan kriteria sesuai instrumen yang dikembangkan. Adapun analisis data tentang jumlah topik-topik Biologi dan jenis kegiatan pembelajaran berbasis komoditas hayati unggulan lokal dilakukan secara deskriptif kuantatif dan kualitatif. Hasil kajian ini menunjukkan nilai aspek-aspek kreativitas guru Biologi yang tinggi, yaitu kemampuan berpikir asli $(91,67)$, peka terhadap masalah $(91,67)$, kemampuan berpikir lancar (90), kemampuan berpikir luwes $(88,33)$, dan kemampuan berpikir terperinci $(86,67)$. Berdasarkan hasil pemetaan yang dilakukan guru, dapat diidentifikasi 15 topik Biologi SMA yang berkaitan dengan komoditas hayati unggulan lokal di Kabupaten Majalengka. Adapun kegiatan pembelajaran berbasis komoditas hayati unggulan yang diusulkan oleh guru tersebar di masing-masing tingkatan kelas dan semesternya dengan jumlah yang berbeda-beda.
\end{abstract}

Kata Kunci: kreativitas, guru Biologi, komoditas hayati unggulan lokal, pembelajaran Biologi SMA

\section{PENDAHULUAN}

Saat ini di Indonesia sektor pertanian masih menjadi sektor unggulan yang memberikan kontribusi terbesar bagi perekonomian nasional dan daerah, baik secara langsung maupun tidak langsung. Indonesia memiliki keunggulan komparatif pada keanekaragaman sumberdaya hayati. Kegiatan ekonomi yang memanfaatkan keunggulan sumberdaya hayati di Indonesia adalah kegiatan pertanian dalam arti luas (Sudaryanto dkk., 2002). Melalui sistem pertanian, kekayaan dan keanekaragaman hayati harus dapat dikelola dan dikembangkan sehingga mampu menjamin ketersediaan pangan. Dalam mendukung keanekaragaman hayati pertanian agar dapat menjamin kedaulatan pangan, masyarakat Indonesia harus menyadari dan wajib mengetahui tentang kekayaan hayati yang dimiliki bangsanya (Sastradipradja \& Widjaya, 2011). Seandainya pemerintah dan masyararakat Indonesia mampu memanfaatkan keanekaragaman hayati, terutama di bidang pertanian dengan baik, masyarakat akan dapat mempertahankan kedaulatan pangannya (Walujo, 2011).

Sains, termasuk Biologi di masa sekarang dan akan datang, diajarkan bukan hanya untuk membekali siswa secara akademik untuk menunjang karir di bidangnya, tetapi harus juga 
membantu siswa menjadi bagian dari masyarakat di kehidupan sosial. Siswa membutuhkan beberapa peluang untuk berpikir ilmiah dan peluang untuk menerapkan penalaran ilmiah dari masalah yang kompleks dalam kehidupan sehari-hari (Balschweid, 2002). Oleh karena itu, setiap strategi pembelajaran harus memperhitungkan kebutuhan konten yang berasal dari kehidupan nyata siswa. Guru di sekolah menengah harus menyampaikan pembelajaran kepada siswa dengan pemahaman yang lebih baik tentang konsep-konsep sains dan relevansinya dalam semua kehidupan kita sehingga mereka akan membantu untuk memecahkan permasalahan siswa yang akan belajar sains di perguruan tinggi (Marshall, 2010). Untuk meningkatkan literasi sains dan pemahaman siswa tentang hakikat sains, siswa harus ditantang untuk berpikir tentang ilmu pengetahuan sebagai sesuatu yang lebih dari sekedar duduk di kelas sains tradisional. Untuk menghasilkan anggota masyarakat di masa yang akan datang, sains harus dibelajarkan dengan penekanan yang sesuai dengan kehidupan sehari-hari dan perannya dalam kegiatan ekonomi (industri dan teknologi) serta kemasyarakatan (Yager, et.al., 2012).

The American Association for the Advancement of Sciences telah menganjurkan bahwa pembelajaran yang efektif dalam sains dimulai dengan pertanyaan tentang alam semesta, melibatkan para siswa dalam kondisi dunia nyata mereka dan menekankan strategi pembelajaran aktif (Washburn \& Myers, 2010). Konten sains dalam pembelajaran di sekolah harus memiliki relevansi pribadi dan sosial, serta kompetensi ilmu pengetahuan di kelas harus dilengkapi dengan kompetensi sosial yang dibutuhkan untuk mengambil tindakan dalam konteks keluarga dan masyarakat (Purwati, 2008). Jika pembelajaran sains dari luar sekolah diintegrasikan ke dalam kurikulum otentik, akan lebih melibatkan dan meningkatkan orientasi positif siswa terhadap sains sehingga pembelajaran lebih menguntungkan (Braund \& Rais, 2006).

Di wilayah pertanian, salah satu konteks pembelajaran yang dapat diintegrasikan dalam pembelajaran adalah komoditas hayati unggulan lokal pertanian. Komoditas unggulan lokal adalah komoditas yang memiliki potensi besar dan dapat dikembangkan, baik karena potensi alam maupun karena komoditas ini dipengaruhi oleh tingkat produksi, skala usaha, dan pemasarannya sebagai upaya menghasilkan produk pertanian yang memiliki keunggulan (Susanto \& Sirappa, 2005). Komoditas hayati unggulan lokal pertanian merupakan konteks yang dekat dengan siswa di wilayah agraria, seperti Indonesia. Sejalan dengan hal tersebut, Hofstein \& Kesner (2006) menyatakan, dalam pengembangan pembelajaran kimia kontekstual di wilayah industri, salah satu prinsip dalam mengintegrasikan industri kimia ke dalam pembelajaran adalah industri yang berperan dalam kepentingan lokal dan berbahan dasar material lokal. Oleh karena itu, konteks komoditas hayati unggulan lokal pertanian memungkinkan untuk dapat diintegrasikan dalam pembelajaran Biologi di sekolah oleh guru di lingkungan wilayah pertanian.

Pembelajaran kontekstual dengan mengintegrasikan komoditas hayati unggulan lokal dalam pembelajaran Biologi membutuhkan pemahaman guru sebagai pengajar dan pengembang kurikulum pembelajaran di kelas. Guru tidak hanya dikenal sebagai pengajar, tetapi berperan pula dalam pengembangan bahan pembelajaran bagi siswa (Oloruntegbe, et.al., 2010). Hofstein \& Kesner (2006) menyatakan, bahwa dalam pembelajaran kimia konteks lokal untuk implementasi atas ambisi mencapai tujuan industri kimia sebagai konteks dalam pembelajaran kimia, membutuhkan usaha dari guru maupun pengembang kurikulum untuk dapat mengintegrasikannya ke dalam pembelajaran. Guru harus menyediakan perangkat pembelajaran dan menentukan strategi pembelajaran yang sesuai dengan kebutuhan pengembangan konteksnya, tidak hanya menggunakan bahan ajar yang sudah ada, tetapi harus mengembangkannya serta memilih strategi pembelajaran yang tepat dalam membelajarkannya.

Saat pengembangan bahan pembelajaran di kelas, berkaitan dengan komoditas hayati unggulan lokal, guru ditantang untuk kreatif sehingga mampu mengintegrasikannya ke dalam pembelajaran. Guru Biologi SMA harus kreatif dan inovatif dalam penerapan dan pengembangan bidang ilmu Biologi dan ilmu-ilmu yang terkait (Depdiknas, 2007). Guru ditantang untuk menghasilkan lingkungan belajar yang dapat membantu siswa dalam memahami sains dan relevansinya yang disesuaikan dengan minat dan kemampuan siswa (Marshall, 2010). Konteks berpikir kreatif guru dalam pembelajaran adalah kemampuan guru dalam menciptakan berbagai ide dan kemungkinankemungkinan baru dan asli, serta kemampuan berpikirnya sebagai hasil refleksi dari wawasan, keingintahuan, kelenturan, dan keaslian, dan kemampuan menghubungkan antara konsep-konsep atau ide-ide yang terkadang dilupakan oleh guru itu 
sendiri ketika menyusun program pembelajaran (Meintjes \& Grosser, 2010). Dalam konteks integrasi komoditas hayati unggulan lokal, guru dituntut dapat melihat fakta bahwa setiap wilayah memiliki komoditas unggulan hayati lokalnya masing-masing. Oleh karena itu, guru harus mampu memetakan aspek-aspek yang berkaitan dengan komoditas hayati unggulan lokal, mulai dari aspek budidaya sampai ke industri pengolahan serta pemasarannya. Selanjutnya, berdasarkan hasil pemetaan ini, guru dapat menghubungkan aspekaspek tersebut dengan topik-topik dalam pembelajaran Biologi di SMA. Pada akhirnya, topik-topik ini yang menjadi konten dan atau konteks dalam pengembangan pembelajaran Biologi berbasis komoditas hayati unggulan lokal oleh guru Biologi SMA.

Berkaitan dengan integrasi komoditas unggulan lokal yang terdiri atas berbagai komoditas dan aspek-aspeknya, terdapat banyak topik yang dapat diintegrasikan ke dalam pembelajaran Biologi. Topik dan informasi yang berkaitan dengan komoditas hayati unggulan lokal tersebut sangat beragam dan tersebar sehingga guru harus mampu memetakannya ke dalam topik-topik pembelajaran Biologi SMA, Dalam menghubungkan aspek-aspek komoditas hayati unggulan lokal ke dalam pembelajaran dapat menggunakan metode mind map. Mind map dapat digunakan untuk mengaitkan ide-ide, berpikir kreatif, dan membuat hubungan antartopik tersebut (Tony Buzan, 2010). Mind map merupakan metode yang digunakan dalam menangkap konsep atau topik yang dianggap relevan dengan masalah atau relevan dengan suatu proses tertentu dalam bentuk representasi visual atas pengetahuan yang terstruktur dan terintegrasi (Keles, 2011). Mind map ini merupakan salah satu cara yang dapat digunakan dalam proses pemecahan masalah yang dapat dilihat secara holistik. Dalam penggunaannya, mind map telah terbukti menjadi alat yang sangat kuat dalam transfer pengetahuan yang menekankan pada interkoneksi berbagai informasi (Diki, 2013).

Pada umumnya guru-guru belum pernah menganalisis komoditas unggulan lokal, tidak mengetahui cara menganalisis komoditas unggulan hayati lokal secara sistematis sehingga guru-guru belum pernah membuat rencana pembelajaran berbasis keanekaragaman hayati unggulan lokal (Sulaeman, dkk., 2012). Mereka tidak mengetahui cara membuat rencana pembelajaran berbasis keanekaragaman hayati unggulan lokal secara sistematis. Mereka tidak mampu menginterkorelasikan topik-topik dari aspek komoditas hayati unggulan lokal dengan pembelajaran Biologi. Kondisi tersebut yang menyebabkan tidak dilakukannya integrasi komoditas hayati lokal ke dalam pembelajaran Biologi SMA. Oleh karena itu, kajian ini dilakukan untuk mengetahui kreativitas guru Biologi SMA untuk memetakan topik-topik dari berbagai aspek komoditas hayati unggulan lokal melalui penggunaan metode mind map. Selanjutnya, kajian ini juga akan melihat kemampuan guru dalam memetakan topik-topik dari komoditas hayati unggulan lokal yang telah dibuat dalam bentuk mind map ke dalam pembelajaran Biologi di SMA.

\section{METODE PENELITIAN}

Penelitian ini menggunakan metode deskriptif, yaitu menggambarkan kreativitas guru dalam menggambarkan topik-topik dari berbagai aspek komoditas hayati unggulan lokal menggunakan metode mind map dan kemampuan memetakan aspek-aspek tersebut ke dalam pembelajaran Biologi di SMA. Kajian ini dilakukan pada bulan April 2014. Pengambilan data dilakukan terhadap kreativitas dan kemampuan pemetaan guru Biologi SMA dari tiap sekolah di kabupaten Majalengka yang mengikuti pendidikan dan pelatihan kreativitas guru Biologi SMA dalam pembelajaran berbasis komoditas hayati unggulan lokal. Responden dalam kajian ini adalah 20 guru Biologi SMA yang menjadi perwakilan dari SMA Negeri dan Swasta yang terdapat di Kabupaten Majalengka.

Instrumen yang digunakan untuk menilai kreativitas guru Biologi SMA yaitu instrumen penilaian mind map yang dihasilkan guru dalam menggambarkan topik-topik yang terkait dengan seluruh aspek salah satu jenis komoditas hayati unggulan lokal. Pengembangan instrumen dilakukan berdasarkan atas komponen-komponen yang terdapat di dalam mind map, yang terdiri atas konten, keberkaitan antar topik, dan desain. Selanjutnya setiap komponen ini dibuatkan deskriptor penilaiannya berdasarkan komponen berpikir kreatif yang dikembangkan oleh Bessemer \& O' Quin, (1986) yang terdiri atas Fluency (kemampuan berpikir lancar), Flexibility (kemampuan berpikir luwes), Originality (kemampuan berpikir asli), Elaboration (kemampuan berpikir terperinci), dan Sensitivity of Problem (peka terhadap masalah). Indikator masing-masing aspek berpikir kreatif tersebut dikembangkan dengan mengaitkan komoditas hayati unggulan lokal sebagai kontennya. Kriteria 
penilaian dari setiap indikator menggunakan skala likert dengan nilai poin 1,2 , dan 3 . Nilai tertinggi dari salah satu aspek mendapat poin 3 dan yang terendah mendapat poin 1. Modifikasi dari Kriteria Asesmen kreativitas (Besmer \& O' Quin, 1986). Adapun untuk menggambarkan pengintegrasian topik-topik dari seluruh aspek komoditas hayati unggulan lokal ke dalam pembelajaran Biologi SMA dilakukan melalui pemetaan topik-topik komoditas hayati unggulan lokal ke dalam konsep/topik Biologi dan kompetensi dasar yang terdapat di pembelajaran Biologi di SMA.

Tabel 1. Instrumen Penilaian Berpikir Kreatif untuk Mind Map

\begin{tabular}{|c|c|c|c|c|}
\hline \multirow{2}{*}{$\begin{array}{l}\text { Komponen } \\
\text { Mind Map }\end{array}$} & \multirow{2}{*}{$\begin{array}{c}\text { Aspek } \\
\text { Kreativitas }\end{array}$} & \multicolumn{3}{|c|}{ Kriteria } \\
\hline & & 3 & 2 & 1 \\
\hline \multirow[t]{4}{*}{ Konten } & $\begin{array}{l}\text { Fluency } \\
\text { (kemampuan } \\
\text { berpikir } \\
\text { lancar) }\end{array}$ & $\begin{array}{l}\text { Menghasilkan banyak } \\
\text { topik yang benar, } \\
\text { inovatif dan menarik } \\
\text { yang memuat komoditas } \\
\text { unggulan hayati local }\end{array}$ & $\begin{array}{l}\text { Menghasilkan banyak } \\
\text { topik inovatif dan } \\
\text { menarik, tetapi tidak } \\
\text { memuat komoditas } \\
\text { unggulan hayati lokal }\end{array}$ & $\begin{array}{l}\text { Tidak menghasilkan } \\
\text { topik inovatif dan } \\
\text { menarik }\end{array}$ \\
\hline & $\begin{array}{l}\text { Flexibility } \\
\text { (kemampuan } \\
\text { berpikir } \\
\text { luwes) }\end{array}$ & $\begin{array}{l}\text { Menghasilkan konten } \\
\text { dengan lengkap, } \\
\text { komprehensif, dan } \\
\text { mendalam untuk satu } \\
\text { topik Biologi dengan } \\
\text { memuat komoditas } \\
\text { unggulan hayati lokal }\end{array}$ & $\begin{array}{l}\text { Menghasilkan konten } \\
\text { dengan lengkap, } \\
\text { komprehensif, dan } \\
\text { mendalam untuk satu } \\
\text { topik Biologi, tetapi } \\
\text { belum memuat } \\
\text { komoditas unggulan } \\
\text { hayati lokal }\end{array}$ & $\begin{array}{l}\text { Tidak menghasilkan } \\
\text { konten yang } \\
\text { lengkap, } \\
\text { komprehensif, dan } \\
\text { mendalam untuk } \\
\text { satu topik Biologi }\end{array}$ \\
\hline & $\begin{array}{l}\text { Originality } \\
\text { (kemampuan } \\
\text { berpikir asli) }\end{array}$ & $\begin{array}{l}\text { Mengemukakan ide atau } \\
\text { pendapat sendiri tentang } \\
\text { topik yang baru } \\
\text { berkaitan dengan } \\
\text { komoditas unggulan } \\
\text { hayati lokal dan } \\
\text { berfungsi praktis }\end{array}$ & $\begin{array}{l}\text { Mengemukakan ide atau } \\
\text { pendapat sendiri tentang } \\
\text { topik yang baru } \\
\text { berkaitan dengan } \\
\text { komoditas unggulan } \\
\text { hayati lokal, tetapi tidak } \\
\text { menunjukkan fungsi } \\
\text { praktis }\end{array}$ & $\begin{array}{l}\text { Tidak } \\
\text { mengemukakan ide } \\
\text { atau pendapat } \\
\text { sendiri tentang } \\
\text { topik berkaitan } \\
\text { dengan komoditas } \\
\text { unggulan hayati } \\
\text { lokal }\end{array}$ \\
\hline & $\begin{array}{l}\text { Sensitivity of } \\
\text { Problem } \\
\text { (peka terhadap } \\
\text { masalah) }\end{array}$ & $\begin{array}{l}\text { Mengemukakan jenis } \\
\text { komoditas hayati } \\
\text { unggulan lokal dengan } \\
\text { jelas dan akurat sebagai } \\
\text { kunci permasalahan } \\
\text { suatu topik mata } \\
\text { pelajaran Biologi }\end{array}$ & $\begin{array}{l}\text { Mengemukakan jenis } \\
\text { komoditas hayati } \\
\text { unggulan lokal dengan } \\
\text { jelas dan akurat hanya } \\
\text { sebagai bagian dari } \\
\text { suatu topik mata } \\
\text { pelajaran Biologi }\end{array}$ & $\begin{array}{l}\text { Tidak } \\
\text { mengemukakan } \\
\text { komoditas hayati } \\
\text { unggulan lokal } \\
\text { dengan jelas dan } \\
\text { akurat }\end{array}$ \\
\hline $\begin{array}{l}\text { Keberkaitan } \\
\text { antartopik }\end{array}$ & $\begin{array}{l}\text { Elaborasi } \\
\text { (kemampuan } \\
\text { berpikir } \\
\text { terperinci) }\end{array}$ & $\begin{array}{l}\text { Hubungan antar topik } \\
\text { dijelaskan dengan baik, } \\
\text { logis, dan rinci }\end{array}$ & $\begin{array}{l}\text { Hubungan antar topik } \\
\text { dijelaskan dengan } \\
\text { kurang baik, logis, dan } \\
\text { rinci }\end{array}$ & $\begin{array}{l}\text { Hubungan antar } \\
\text { topik tidak } \\
\text { dijelaskan dengan } \\
\text { baik, logis, dan rinci }\end{array}$ \\
\hline Desain & $\begin{array}{l}\text { Elaborasi } \\
\text { (kemampuan } \\
\text { berpikir } \\
\text { terperinci) }\end{array}$ & $\begin{array}{l}\text { Menyajikan topik } \\
\text { dengan inovatif, } \\
\text { menarik, dan luar biasa }\end{array}$ & $\begin{array}{l}\text { Menyajikan topik } \\
\text { dengan kurang inovatif, } \\
\text { menarik, dan luar biasa }\end{array}$ & $\begin{array}{l}\text { Menyajikan topik } \\
\text { dengan tidak } \\
\text { inovatif, menarik, } \\
\text { dan luar biasa }\end{array}$ \\
\hline
\end{tabular}


Setiap topik komoditas hayati unggulan lokal harus dipetakan seluruh aspek pendukungnya, baik dari budidaya, industri pengolahan, pembibitan, dan pemeliharaannya ke dalam pembelajaran. Melalui pemetaan ini akan teridentifikasi jumlah topik dan jenis kegiatan pembelajaran yang berkaitan di seluruh pembelajaran Biologi SMA pada setiap jenjang kelasnya.

Analisis data terhadap mind map dan pemetaan topik-topik menggambarkan kemampuan guru dalam memetakan aspek-aspek komoditas hayati unggulan lokal ke dalam pembelajaran Biologi SMA. Analisis data kreativitas guru Biologi SMA dilakukan secara deskriptif kuantitatif terhadap mind map dengan menggunakan kriteria sesuai instrumen yan dikembangkan. Adapun analisis data tentang jumlah topik-topik Biologi dan jenis kegiatan pembelajaran berbasis komoditas hayati unggulan lokal dilakukan secara deskriptif kuantatif dan kualitatif.

\section{HASIL DAN PEMBAHASAN}

\section{Kreativitas Guru Biologi dalam Memetakan Topik Komoditas hayati Unggulan Lokal}

Merriam Webster (Dailey, et.al., 2001) menjelaskan, bahwa pertanian menurut definisi adalah menerapkan ilmu yang mengombinasikan prinsip-prinsip kimia, fisik, dan Biologi dalam proses dan produksi makanan dan serat. Komoditas hayati unggulan lokal merupakan bagian dari pertanian yang terdiri atas tanaman bahan pangan, perkebunan, kehutanan, peternakan, dan perikanan. Saat ini pengembangan pertanian dalam mendukung kegiatan ekonomi wilayah terjadi melalui agribisnis. Dalam sistem agribisnis, sangat penting menentukan komoditas yang memiliki potensi besar dan dapat dikembangkan, baik karena potensi alam maupun karena dipengaruhi oleh tingkat produksi, skala usaha, dan pemasarannya sebagai upaya daerah dalam menghasilkan produk pertanian yang memiliki keunggulan (Susanto \& Sirappa, 2005). Artinya, dalam sistem agribisnis, pengembangan komoditas unggulan tidak terbatas pada skala budidaya saja, melainkan juga pada seluruh aspek yang terkait, mulai dari pembibitan, budidaya, pemeliharan, produksi olahan, dan pemasarannya termasuk dari segi pembiayaan. Dari keseluruhan aspek komoditas hayati unggulan lokal tersebut terdapat topik-topik yang berkaitan dengan topik-topik Biologi di SMA, baik dari jenis komoditas itu sendiri, maupun dari proses-proses yang terjadi dalam usaha pengembangannya. Seluruh topik dari komoditas hayati unggulan lokal tersebut harus dipetakan dengan lengkap dan digambarkan keberkaitan antar aspeknya. Salah satu metode yang dapat digunakan untuk pemetaan aspek-aspek komoditas hayati unggulan lokal adalah mind map. Metode mind map ini dapat digunakan guru memetakan pengetahuan dan informasi tentang topik-topik dari seluruh aspek komoditas hayati unggulan lokal dengan lengkap. Mind map yang dihasilkan guru ini merupakan bentuk kreativitas guru dalam konteks komoditas hayati unggulan lokal. Selain mampu memudahkan memahami dan memanggil kembali informasi, penggunaan mind map ini dapat menunjukkan inovasi dan kemampuan berpikir kreatif guru (Diki, 2013).

Kemampuan berpikir kreatif guru Biologi dalam memetakan komoditas hayati unggulan lokal melalui penggunaan mind map dapat terlihat pada Gambar 1. Gambar tersebut menunjukkan kreativitas guru Biologi berdasarkan masingmasing aspek berpikir kreatif.

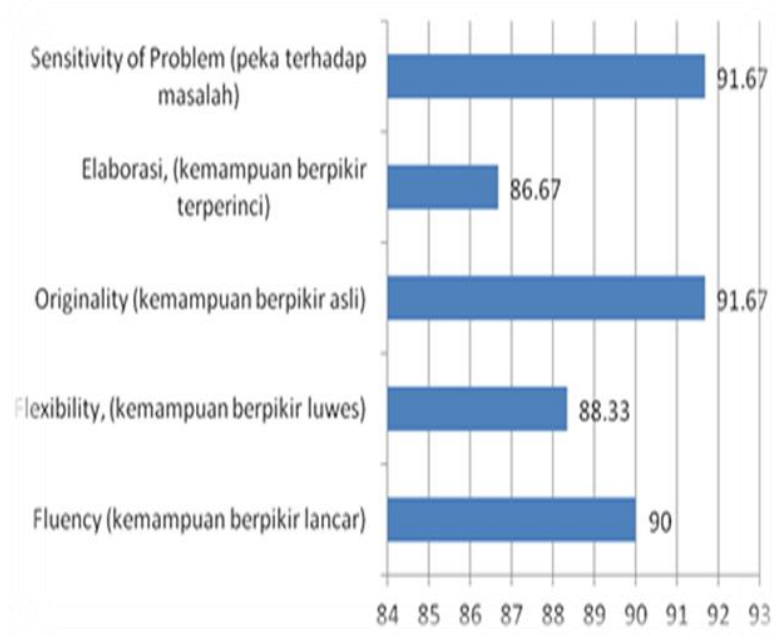

Gambar 1. Kreativitas Guru dalam Memetakan Komoditas Hayati unggulan Lokal

Pada umumnya, guru sudah dapat memetakan dan mengaitkan topik-topik dari seluruh aspek komoditas hayati unggulan lokal sebagai hasil kreativitasnya. Berdasarkan Gambar 1 tampak bahwa aspek-aspek kreativitas guru Biologi yang menunjukkan data dengan nilai tinggi adalah aspek kemampuan berpikir asli $(91,67)$, peka terhadap masalah $(91,67)$, dan kemampuan berpikir lancar (90). Adapun aspek kreativitas yang menunjukan nilai lebih rendah adalah kemampuan berpikir luwes $(88,33)$, dan kemampuan berpikir terperinci $(86,67)$. Data tersebut menunjukan bahwa guru mampu menghasilkan banyak topik dari aspek-apek komoditas hayati unggulan lokal. 
Kemampuan membuat integrasi dari berbagai materi atas subjek yang berbeda merupakan bagian penting dari kreativitas (Diki, 2013). Dengan menggunakan mind map guru-guru mampu mengidentifikasi banyak topik dari seluruh aktivitas agribisnis komoditas hayati unggulan lokal. Kondisi tersebut bisa terjadi karena guru telah mampu meningkatkan pengetahuan dan memfokuskan informasi yang mereka miliki yang dialami di kehidupan sehari-hari berkaitan dengan komoditas hayati unggulan lokal dengan bantuan mind map. Selama ini mereka belum mengetahui prosedur yang tepat dalam mengorganisasi pengetahuan dan informasi yang dimiliki tentang komoditas hayati unggulan lokal. Metode mind map ini membantu guru dalam membuat peta organisasi dari banyak pengetahuan dan informasi tentang komoditas hayati unggulan lokal dengan baik, berdasarkan apa yang mereka lihat dan ketahui di kehidupan sehari-hari, maupun hasil diskusi dengan orang lain yang terjadi sebelumnya.

Mind map yang dihasilkan tersebut merupakan produk berpikir kreatif guru tentang komoditas hayati unggulan lokal. Berpikir kreatif merupakan kemampuan penting dalam mengeksplorasi berbagai alternatif cara dalam mengkonseptualkan sebuah permasalahan melalui berbagai sumber informasi menjadi kerangka aplikasi yang beragam. Artinya, melalui mind map ini guru mampu menjawab permasalahan tentang topik-topik apa saja yang terkait dengan komoditas hayati unggulan lokal yang akan bermakna dalam pembelajaran Biologi sehingga dapat dibelajarkan kepada siswa. Melalui mind map tampak guru-guru Biologi sudah memahami bahwa komoditas hayati unggulan lokal dapat menjadi konteks dan konten dalam mata pelajaran Biologi sehingga memungkinkan terwujudnya pembelajaran Biologi yang lebih bermanfaat bagi kehidupan siswa.

\section{Kemampuan guru Biologi SMA dalam Memetakan Komoditas Hayati Unggulan Lokal ke dalam Pembelajaran}

Pemetaan aspek-aspek komoditas hayati unggulan lokal diawali dengan analisis komoditas hayati unggulan lokal yang ada pada dokumen perencanaan di daerah. Berdasarkan hasil analisis dokumen program kerja lima tahun Dinas Pertanian dan perikanan serta roadmap komoditas unggulan lokal dari kantor Bappeda Kabupaten Majalengka, dapat diidentifikasi beberapa jenis komoditas hayati unggulan lokal. Selanjutnya dalam pengembangan pembelajaran berbasis komoditas hayati unggulan lokal, ada sepuluh jenis komoditas hayati unggulan lokal dengan peringkat tertinggi. Jenis-jenis komoditas hayati unggulan lokal yang dipilih terdiri atas jagung (Zea mays), padi (Oryza sativa L.), kentang (Solanum tuberosum L.), ubi jalar (Ipomoea batatas L.), bawang merah (Allium cepa L.), cabe merah (Capsicum annuum L.), mangga (Mangifera indica), durian (Durio zibethinus), nila (Oreochromis niloticus), dan gurame (Osphronemus gouramy L.). Kemudian, guru Biologi memetakan topik-topik dari seluruh aspek untuk sepuluh jenis komoditas hayati unggulan lokal tersebut dengan menggunakan mind map. Berdasarkan mind map, topik-topik dari seluruh aspek komoditas hayati unggulan lokal dipetakan ke dalam topik-topik Biologi. Berikut ini contoh topik-topik Biologi hasil pemetaan dari aspek-aspek komoditas hayati unggulan lokal yang dilakukan oleh guru (Tabel 2).

Sebagian besar guru Biologi memetakan komoditas hayati unggulan lokal berdasarkan aspeknya, terutama untuk jenis tanaman. Aspekaspek yang digunakan dalam memetakan komoditas hayati unggulan lokal adalah aspek organ tanaman yang terdiri batang, daun, dan akar, serta aspek pembenihan, aspek pemeliharaan, aspek produksi, aspek reproduksi, dan aspek hama/penyakit pengganggu tanaman. Aspek-aspek ini lah yang kemudian dipetakan ke dalam topik-topik Biologi yang relevan. Tabel 2 menunjukkan bahwa tidak semua jenis komoditas unggulan dapat memunculkan jumlah topik Biologi relevan yang sama. Beberapa jenis komoditas unggulan lokal memiliki relevansi dengan banyak topik Biologi. Adapun beberapa jenis komoditas hayati unggulan lokal lainnya memiliki sedikit relevansi dengan topik Biologi. Jumlah terkecil topik Biologi yang dapat dikaitkan dengan komoditas hayati unggulan lokal adalah dari jenis komoditas ikan nila dan gurame, yaitu 4 topik Biologi. Adapun jumlah topik Biologi terbanyak yang dikaitkan dengan komoditas unggulan lokal adalah dari jenis komoditas kentang dan ubi jalar, yaitu 11 topik terlihat pada Gambar 2. 
Tabel 2. Pemetaan Aspek Komoditas Hayati Unggulan Lokal dan Topik Biologi SMA

\begin{tabular}{|c|c|c|c|}
\hline No & Jenis Komoditas & $\begin{array}{c}\text { Aspek } \\
\text { Komoditas }\end{array}$ & Topik Biologi Terkait \\
\hline \multirow[t]{2}{*}{1.} & \multirow{2}{*}{$\begin{array}{l}\text { Nila (Oreochromis } \\
\text { niloticus) }\end{array}$} & Nilai Gizi & Makanan \\
\hline & & $\begin{array}{l}\text { Pembenihan/ Pemeliharaan } \\
\text { Manfaat } \\
\text { Tubuh Ikan }\end{array}$ & $\begin{array}{l}\text { Pertumbuhan dan Perkembangan } \\
\text { Keanekaragaman Hewan } \\
\text { Morfologi dan Klasifikasi Hewan }\end{array}$ \\
\hline \multirow[t]{2}{*}{2.} & \multirow{2}{*}{$\begin{array}{l}\text { Padi } \\
\text { (Oryza sativa } \mathrm{L})\end{array}$} & Nilai Gizi & Makanan \\
\hline & & $\begin{array}{l}\text { Pembenihan/ Pemeliharaan } \\
\text { Manfaat } \\
\text { Morfologi Monokotil } \\
\text { Varietas } \\
\text { Jerami } \\
\text { Sekam } \\
\text { Hama } \\
\text { Batang, Akar, Daun } \\
\text { Morfologi Dikotil }\end{array}$ & $\begin{array}{l}\text { Pertumbuhan dan Perkembangan } \\
\text { Keanekaragaman Tumbuhan } \\
\text { Morfologi dan Klasifikasi Tumbuhan } \\
\text { Keanekaragaman Tumbuhan } \\
\text { Keanekaragaman Tumbuhan dan Ekologi } \\
\text { Keanekaragaman Tumbuhan dan Ekologi } \\
\text { Keanekaragaman Hewan } \\
\text { Anatomi, Struktur Jaringan, dan Fisiologi Tumbuhan } \\
\text { Morfologi dan Klasifikasi Tumbuhan }\end{array}$ \\
\hline \multirow{2}{*}{3.} & \multirow{2}{*}{$\begin{array}{l}\text { Mangga } \\
\text { (Mangifera indica) }\end{array}$} & $\begin{array}{l}\text { Morfolog1 Dikotil } \\
\text { Analisis Varietas }\end{array}$ & $\begin{array}{l}\text { Morfolog1 dan Klasıf1kas1 I umbuhan } \\
\text { Keanekaragaman Tumbuhan }\end{array}$ \\
\hline & & $\begin{array}{l}\text { Batang, Akar, Daun } \\
\text { Manfaat } \\
\text { Perbanyakan bibit } \\
\text { Nilai Gizi } \\
\text { Hama } \\
\text { Penyakit }\end{array}$ & $\begin{array}{l}\text { Anatomi, Struktur Jaringan, dan Fisiologi Tumbuhan } \\
\text { Keanekaragaman Tumbuhan } \\
\text { Reproduksi vegetatif } \\
\text { Makanan } \\
\text { Keanekaragaman Hewan } \\
\text { Keanekaragaman Monera dan Jamur }\end{array}$ \\
\hline
\end{tabular}

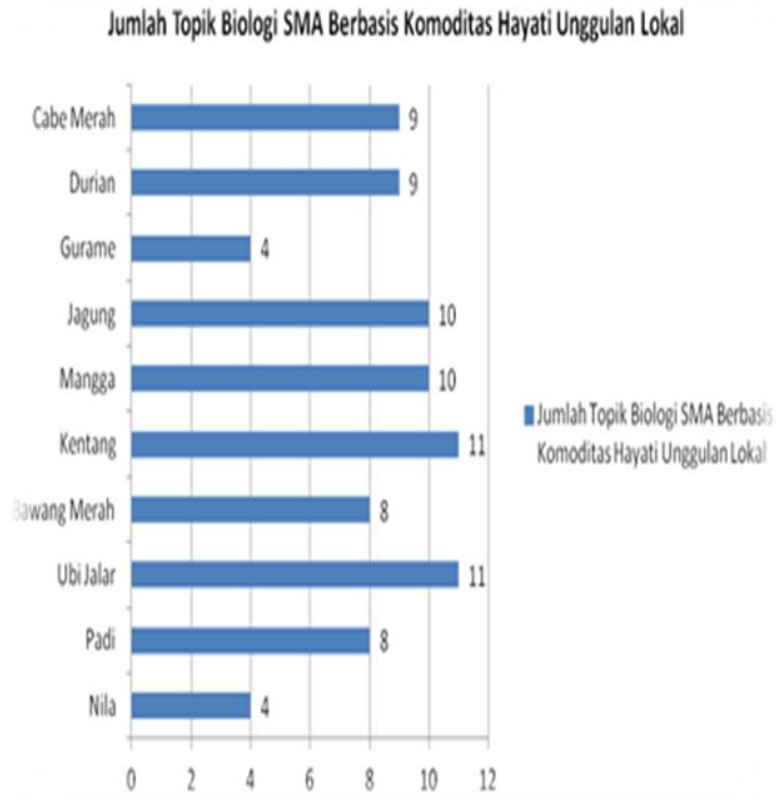

Gambar 2. Jumlah Topik Biologi SMA Berbasis Komoditas Hayati Unggulan Lokal

Selanjutnya dilakukan rekapitulasi topiktopik Biologi yang terpetakan dari sepuluh jenis komoditas hayati unggulan lokal. Berikut ini topiktopik Biologi SMA yang dapat dipetakan oleh guru Biologi SMA dari 10 jenis komoditas hayati unggulan lokal yang terdapat di Kabupaten Majalengka.
Tabel 3. Topik Biologi SMA Terkait Komoditas Hayati Unggulan Lokal

\begin{tabular}{ll}
\hline No & $\begin{array}{l}\text { Topik Biologi Terkait Komoditas Hayati } \\
\text { Unggulan Lokal }\end{array}$ \\
\hline 1. & Makanan \\
2. & Pertumbuhan dan Perkembangan \\
3. & Keanekaragaman Protista \\
4. & Keanekaragaman Jamur \\
5. & Keanekargaman Hewan \\
6. & Keanekaragaman Tumbuhan \\
7. & Klasifikasi Hewan \\
8. & Klasifkasi Tumbuhan \\
9. & Ekologi \\
10. & Struktur dan Fungsi Jaringan Tumbuhan \\
11. & Struktur dan Fungsi Jaringan Hewan \\
12. & Reproduksi Tumbuhan \\
13. & Fisiologi Tumbuhan \\
14. & Bioteknologi \\
15. & Metabolisme Seluler \\
\hline
\end{tabular}

Hasil pemetaan yang dilakukan guru, dapat diidentifikasi 15 topik Biologi SMA yang berkaitan dengan komoditas hayati unggulan lokal di Kabupaten Majalengka. Topik-topik Biologi ini tersebar di dalam stuktur kurikulum SMA pada mata pelajaran Biologi di semua tingkatan kelas. Untuk dapat mengetahui sebaran topik-topik Biologi di masing-masing tingkatan kelas, guru 
menganalisis Standar Kompetensi mata pelajaran Biologi SMA yang terdapat dalam struktur kurikulum SMA (Permendikbud Nomor 69 Tahun 2013). Topik-topik tersebut dipetakan ke dalam kompetensi dasar yang ada. Selanjutnya, guru memetakan kompetensi dalam mata pelajaran Biologi yang akan dibelajarkan melalui komoditas hayati unggulan lokal. Di dalam peta ini juga guru- guru Biologi mengusulkan bentuk kegiatan pembelajarannya dengan menyusun deskripsi singkat pembelajaran. Tabel 4 . berikut ini berisi contoh usulan kegiatan yang dapat menjadi alternatif acuan dalam mengembangkan rencana pembelajaran dan lembar kegiatan siswa Biologi SMA berbasis komoditas hayati unggulan lokal di setiap tingkatan kelas.

Tabel 4. Pemetaan Pembelajaran Biologi Berbasis

Komoditas Hayati Unggulan Lokal

\begin{tabular}{|c|c|c|c|c|c|}
\hline No & Jenis Komoditas & Topik Biologi & KD & Deskripsi Singkat & $\begin{array}{c}\text { Kelas/ } \\
\text { Semester }\end{array}$ \\
\hline \multirow[t]{5}{*}{1.} & $\begin{array}{l}\text { Nila (Oreochromis } \\
\text { niloticus) }\end{array}$ & Makanan & 3.7 & $\begin{array}{l}\text { Uji makanan daging nila dan } \\
\text { komoditas lainnya }\end{array}$ & $\mathrm{XI} / 2$ \\
\hline & & Pertumbuhan dan & 3.1., & Pengaruh perlakuan (faktor & $\mathrm{XII} / 1$ \\
\hline & & Perkembangan & 4.1. & $\begin{array}{l}\text { luar) terhadap pertumbuhan } \\
\text { ikan nila }\end{array}$ & \\
\hline & & Keanekaragaman Hewan & $3.8 ., 4.8$ & Pembuatan abon nila & $\mathrm{X} / 2$ \\
\hline & & Morfologi dan Klasifikasi & $3.8 ., 4.8$ & Pengenalan morfologi Ikan nila & $\mathrm{X} / 2$ \\
\hline \multirow[t]{10}{*}{2.} & $\begin{array}{l}\text { Padi } \\
\text { (Oryza sativa } \mathrm{L})\end{array}$ & Makanan & 3.7 & $\begin{array}{l}\text { Uji makanan padi dan } \\
\text { komoditas lainnya }\end{array}$ & $\mathrm{XI} / 2$ \\
\hline & & Pertumbuhan dan & 3.1., & Pengaruh perlakuan (faktor & $\mathrm{XII} / 1$ \\
\hline & & Perkembangan & 4.1. & luar) terhadap padi & \\
\hline & & Keanekaragaman Tumbuhan & $3.8 ., 4.8$ & Pembuatan berem & $\mathrm{X} / 2$ \\
\hline & & Morfologi dan Klasifikasi & $\begin{array}{l}3.7 . \\
4.7\end{array}$ & Pengenalan morfologi padi & $\mathrm{X} / 2$ \\
\hline & & Keanekaragaman Tumbuhan & $\begin{array}{l}3.2 . \\
4.2 .\end{array}$ & $\begin{array}{l}\text { Membedakan morfologi } \\
\text { beberapa varietas padi }\end{array}$ & $\mathrm{X} / 1$ \\
\hline & & Keanekaragaman Tumbuhan & $\begin{array}{l}3.9 . \\
4.9\end{array}$ & $\begin{array}{l}\text { Pembuatan Media Jamur } \\
\text { Merang }\end{array}$ & $\mathrm{X} / 2$ \\
\hline & & Keanekaragaman Tumbuhan & $\begin{array}{l}3.9 . \\
4.9\end{array}$ & Pembuatan Briket sekam padi & $\mathrm{X} / 2$ \\
\hline & & Keanekaragaman Hewan & 3.8., 3.9 & $\begin{array}{l}\text { Klasifikasi insekta pengganggu } \\
\text { padi }\end{array}$ & $\mathrm{X} / 2$ \\
\hline & & $\begin{array}{l}\text { Anatomi, struktur jaringan, } \\
\text { dan Fisiologi Tumbuhan }\end{array}$ & $3.3 ., 4.3$ & $\begin{array}{l}\text { Mengamati morfologi dan } \\
\text { membuat preparat }\end{array}$ & $\mathrm{XI} / 1$ \\
\hline \multirow[t]{8}{*}{6.} & Mangga & Morfologi dan Klasifikasi & $3.7 ., 4.7$ & Pengenalan morfologi mangga & $\mathrm{X} / 2$ \\
\hline & (Mangifera indica) & Keanekaragaman Tumbuhan & 3.2.,4.2. & $\begin{array}{l}\text { Membedakan morfologi } \\
\text { beberapa varietas mangga }\end{array}$ & $\mathrm{X} / 1$ \\
\hline & & $\begin{array}{l}\text { Anatomi, struktur jaringan, } \\
\text { dan Fisiologi Tumbuhan }\end{array}$ & $3.3 ., 4.3$ & $\begin{array}{l}\text { Mengamati morfologi dan } \\
\text { membuat preparat }\end{array}$ & $\mathrm{XI} / 1$ \\
\hline & & Keanekaragaman Tumbuhan & $\begin{array}{l}3.9 . \\
4.9\end{array}$ & $\begin{array}{l}\text { Pembuatan pure, dodol } \\
\text { mangga, keripik manga }\end{array}$ & $\mathrm{X} / 2$ \\
\hline & & Perbanyakan Mangga & $\begin{array}{l}3.3 . \\
4.3\end{array}$ & Stek mangga empat varietas & $\mathrm{XI} / 1$ \\
\hline & & Makanan & 3.7 & $\begin{array}{l}\text { Uji makanan mangga dan } \\
\text { komoditas lainnya }\end{array}$ & $\mathrm{XI} / 2$ \\
\hline & & Keanekaragaman hewan & $3.8 ., 3.9$ & $\begin{array}{l}\text { Klasifikasi insekta pengganggu } \\
\text { manga }\end{array}$ & $\mathrm{X} / 2$ \\
\hline & & $\begin{array}{l}\text { Keanekaragaman Monera } \\
\text { dan Jamur }\end{array}$ & $\begin{array}{l}3.6 . \\
4.6\end{array}$ & $\begin{array}{l}\text { Identifikasi jamur penyebab } \\
\text { penyakit pada mangga }\end{array}$ & $\mathrm{X} / 1$ \\
\hline
\end{tabular}


Berdasarkan table contoh hasil analisis tersebut dapat diketahui terdapat beberapa kegiatan pembelajaran yang sama dengan objek yang berbeda dari beberapa jenis komoditas berbeda untuk satu jenis kompetensi dasar. Artinya, setiap usulan kegiatan pembelajaran tersebut dapat dijadikan pilihan alternatif pembelajaran Biologi berbasis komoditas hayati unggulan lokal. Dalam implementasinya, guru bisa memilih kegiatan pembelajaran yang disesuaikan dengan ketersediaan bahan dan konteks yang lebih autentik di lingkungan sekolahnya. Beberapa jenis kegiatan lainnya menunjukkan kegiatan yang sama yang diusulkan dari jenis komoditas berbeda. Dalam implementasinya, untuk jenis kegiatan pembelajaran tersebut dapat dibuat gabungan kegiatan yang sama dengan objek yang beragam.

Berdasarkan sebarannya, dapat diketahui adanya perbedaan jumlah kegiatan pembelajaran berbasis komoditas hayati unggulan yang diusulkan oleh guru untuk masing-masing tingkatan kelas dan semesternya. Berikut ini gambar sebaran usulan kegiatan pembelajaran berbasis komoditas hayati unggulan lokal untuk setiap tingkatan kelas dan semesternya.

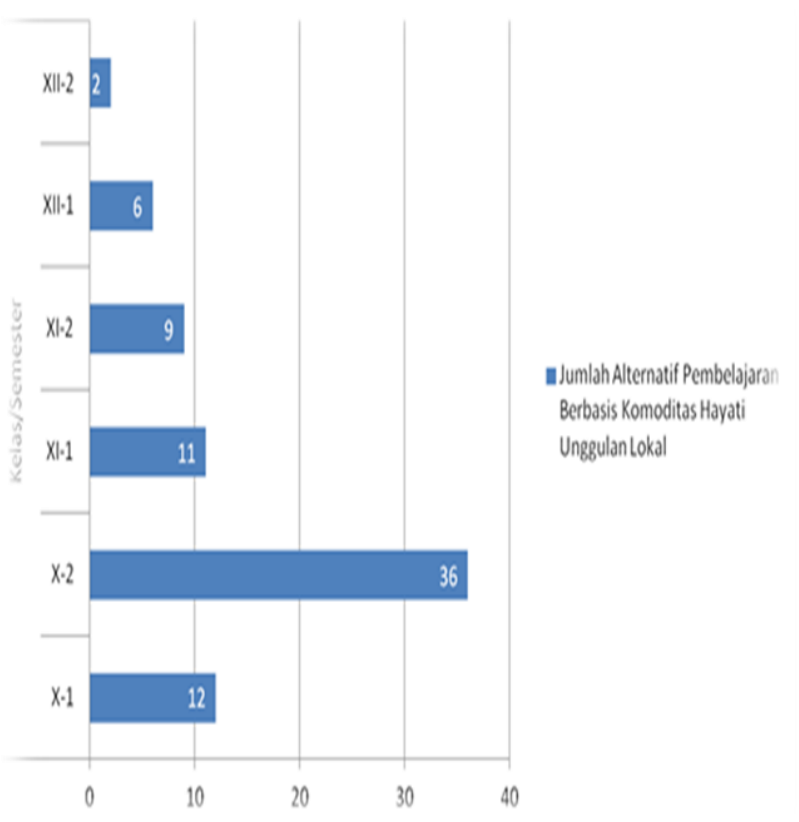

Gambar 3. Sebaran Usulan Alternatif Kegiatan Pembelajaran Biologi Berbasis

Komoditas Hayati Unggulan Lokal

Berdasarkan Gambar 3. tersebut, dapat diamati jumlah alternatif usulan kegiatan pembelajaran berbasis komoditas hayati unggulan lokal di setiap jenjang dan semesternya berbedabeda. Jumlah terbanyak usulan kegiatan pembelajaran berbasis komoditas hayati unggulan lokal terdapat di kelas X semester 2. Kondisi ini berkaitan dengan kompetensi dasar yang terdapat di kelas $\mathrm{X}$ semester 2 yang memuat kompetensi yang berkaitan dengan konten keanekaragaman dan klasifikasi hewan serta tumbuhan. Seperti telah diketahui, jenis-jenis komoditas hayati unggulan lokal yang diintegrasikan ke dalam pembelajaran adalah kelompok hewan dan tumbuhan sehingga memiliki relevansi yang tinggi dengan konten tersebut. Selain itu, aspek-aspek lain yang memiliki relevansi dengan komoditas hayati unggulan lokal merupakan bagian dari konten yang terdapat pada kompetensi dasar lainnya di kelas X semester 2, misalnya pengolahan limbah organik komoditas yang sesuai dengan kompetensi tentang pengelolaan lingkungan. Adapun jumlah paling sedikit terkait usulan alternatif kegiatan pembelajaran berbasis komoditas hayati unggulan lokal terdapat di kelas XII semester 2. Pada semester ini terdapat kompetensi dasar yang berkaitan dengan konten genetika, evolusi, dan bioteknologi. Saat ini, konten-konten tersebut kurang memiliki relevansi dengan komoditas hayati unggulan lokal di Majalengka sehingga guru-guru Biologi hanya mengusulkan dua jenis kegiatan pembelajaran, yang berkaitan dengan bioteknologi, yaitu pembuatan donat kentang dan donat ubi jalar.

\section{PENUTUP}

Pembelajaran bermakna bergantung pada kemampuan siswa mengenal relevansi dan kebermanfaatan pembelajaran tersebut dan bisa mengaplikasikannya. Di wilayah pertanian, salah satu konteks yang relevan yang dapat dibelajarkan kepada siswa melalui pendidikan Biologi adalah komoditas hayati unggulan lokal sehingga dapat memberikan kebermanfaatan kepada siswa. Dalam pelaksanaannya, pembelajaran Biologi berbasis komoditas hayati unggulan lokal ini membutuhkan kreativitas guru untuk dapat memetakan aspekaspek komoditas hayati unggulan lokal ke dalam pembelajaran Biologi di SMA. Berdasarkan hasil kajian ini, kreativitas guru dalam memetakan komoditas hayati unggulan lokal ke dalam pembelajaran menunjukan nilai yang tinggi untuk setiap aspek kreativitas, yaitu kemampuan berpikir asli $(91,67)$, peka terhadap masalah $(91,67)$, kemampuan berpikir lancar (90), kemampuan berpikir luwes $(88,33)$, dan kemampuan berpikir terperinci $(86,67)$.

Guru-guru Biologi SMA di Kabupaten Majalengka juga telah mampu mengidentifikasi topik-topik Biologi yang memiliki relevansi dengan 
aspek-aspek komoditas hayati unggulan lokal sebanyak lima belas buah topik. Selain itu, guruguru Biologi telah mengusulkan alternatif-alternatif kegiatan pembelajaran Biologi SMA yang berbasis komoditas hayati unggulan lokal di wilayahnya. Kegiatan pembelajaran Biologi tersebut tersebar di masing-masing tingkatan kelas dan semesternya dengan jumlah yang berbeda-beda.

Selanjutnya, kreativitas guru Biologi juga harus terus dikembangkan dalam konteks pengembangan pembelajaran berbasis komoditas hayati unggulan lokal. Dalam aplikasinya, guru tidak hanya dituntut untuk kreatif dalam memetakan aspek-aspek komoditas hayati unggulan lokal ke dalam topik-topik pembelajaran Biologi di SMA. Akan tetapi, mereka juga dituntut untuk kreatif mengimpelentasikan pembelajaran berbasis komoditas hayati unggulan lokal, mulai dari merancang rencana pelaksanaan pembelajaran, merancang lembar kegiatan siswa, dan pelaksanaan kegiatan pembelajarannya. Oleh karena itu, guru ditutut harus terus kreatif dalam mengembangkan pembelajaran berbasis komoditas hayati unggulan lokal sehingga mampu memberikan pembelajaran bermakna bagi siswanya.

\section{DAFTAR PUSTAKA}

Balschweid M. 2002. Teaching Biology Using Agriculture as The Context: Preceptions of High School Students. Journal of Agricultural Education 56 43(2).

Balschweid M, Huerta. 2008. Teaching Advanced Life in Animal Context: Agricultural Science Teacher Voices. Journal of Agricultural Education 49(1).

Bessemer, O'Quin. 1986. Analyzing Creative Product: Refinement and Test of Judging Instrument. Journal of Creative Behaviour. 20(2):107-114.

Braund M, Reiss M. 2006. Toward a More Authentic Science Curiculum : The Contribution of Out-of-School Learning. 2006. International Journal of Science Education 28(12): 1373-1388.

Dailey AL, Conroy CA, Shelley-Tolbert CA. 2001. Using Agricultural Education's The Context to Teach Life Skills. Journal of Agricultural Education 49(1):17-27.

Depdiknas. 2007. Peraturan Pemerintah Nomor 16 Tahun 2007 tentang Standar Kualifikasi Akademik dan Kompetensi Guru. Jakarta.
Diki D. 2013. Creativity for Learning Biologi in Higher Education. Lux: A Journal of Trandisciplinary Writing and Research from Claremont Graduated University 3(1).

Hofstein A, Kesner M. (2006). Industrial Chemistry and School Chemistry: Making Chemistry Studies more Relevant. International Journal of Science Education 28(9):1017-1039.

Keles O. 2011. Mind Maps and Scoring Scale for Environmenttal Gains in Science Education. International conference on New Horizons in Education Conference Proceedings Book.

Marshal G. 2010. Student Centered, Active Learning Pedagogies in Chemistry Education. Making Chemistry Relevant, Sharsmistha, B. (ed.). A John Wiley \& Sons, Inc., New Jersey.

Meintjes H, Grosser M. 2010. Creative Thinking in Prosfectif Teacher: The Status Quo and The imfact of Contextual factor. South African Journal of Education 30:361-386.

NRC. 1996. National Science Education Standards. Washington DC : National Academic Press.

Oloruntegbe, et.al. 2010. Teachers' Involvement, Commitment and Innovativeness in Curriculum Development and Implementation. Educational Research 1(12):706-712.

Purwati T. 2008. KTSP, Prospek dan Problema dalam Tataran Aplikasinya. Paradigma, Tahun XIII, Nomor 25. Januari-Juni 2008.

Sastradipradja SD, Widjaja EA, 2010. Keanekaragaman Hayati Pertanian Menjamin Kedaulatan Pangan. LIPI Press; Jakarta.

Sudaryanto T, Rusastra IW, Simatupang P. 2002. Strategi dan Kebijakan Pembangunan Ekonomi Pedesaan Berbasis Agribisnis. Prosiding Seminar dan Ekspose Hasil Penelitian/Pengkajian BPTP Jawa Timur. BPTP Jawa Timur: Surabaya.

Susanto AN, Sirappa MP. 2005. Prospek dan Strategi Pengembangan Jagung untuk Mendukung Ketahanan Pangan di Maluku. Jurnal Litbang Pertanian 24(2):70-79. 
Walujo E B. 2011. Keanekaragaman Hayati untuk Pangan. Disampaikan Pada Konggres Ilmu Pengetahuan Nasional X, Jakarta, 8-10 Nopember 2011. Diunduh Dari Http://Www.Opi.Lipi.Go.Id/.Makalah.Pdf
Yager SO, Dogan OK, Haceeminoglu E, Yager RE. 2012. The Role of Student and Teacher Creativity in Aiding Current Reform Efforts in Science and Technology Education. National Forum of Applied Educational Research Journal 25(3):1-22. 
Kreativitas Guru Biologi dalam Memetakan Komoditas Hayati Unggulan Lokal 